\title{
A dinâmica da pesca artesanal na Bacia de Campos: organização social e práticas em economia solidária entre os pescadores artesanais
}

The Dynamics of Artisanal Fisheries in the Bacia de Campos: Social Organization and Practices in Solidarity Economy among Artisanal Fishermen

La dynamique de la pêche artisanale à Bacia de Campos: organisation sociale et pratiques de l'économie solidaire entre pêcheurs

Mauro Macedo Campos, Geraldo Márcio Timóteo e Ana Paula Serpa Nogueira de Arruda

\section{OpenEdition}

\section{Journals}

Edição electrónica

URL: http://journals.openedition.org/rccs/7227

DOI: $10.4000 /$ rccs.7227

ISSN: $2182-7435$

\section{Editora}

Centro de Estudos Sociais da Universidade de Coimbra

Edição impressa

Data de publição: 1 setembro 2018

Paginação: 71-102

ISSN: 0254-1106

Refêrencia eletrónica

Mauro Macedo Campos, Geraldo Márcio Timóteo e Ana Paula Serpa Nogueira de Arruda, «A dinâmica da pesca artesanal na Bacia de Campos: organização social e práticas em economia solidária entre os pescadores artesanais ", Revista Crítica de Ciências Sociais [Online], 116 | 2018, posto online no dia 31 julho 2018, consultado o 12 setembro 2020. URL : http://journals.openedition.org/rccs/7227 ; DOI : https://doi.org/10.4000/rccs.7227 


\title{
MAURO MACEDO CAMPOS, GERALDO MÁRCIO TIMÓTEO, ANA PAULA SERPA NOGUEIRA DE ARRUDA
}

\section{A dinâmica da pesca artesanal na Bacia de Campos: organização social e práticas em economia solidária entre os pescadores artesanais}

\begin{abstract}
Este artigo apresenta os desafios para a implementação de um projeto de economia solidária junto aos pescadores artesanais da Bacia de Campos, no Brasil. O estudo é fruto das pesquisas realizadas pelo Projeto PEA Pescarte, uma parceria entre UENF/Petrobras/IBAMA. As informações deste trabalho foram coletadas em reuniões nas comunidades dos pescadores, grupos focais e questionários aplicados de forma censitária. Os achados evidenciam a falta de confiança dos pescadores artesanais no Estado e nas instituições representativas. Por outro lado, apontam para a solidariedade e a visão de que o trabalho cooperado e a organização social são elementos essenciais para alterar a realidade socioeconômica destes sujeitos.
\end{abstract}

Palavras-chave: economia solidária; educação ambiental; organização social; pesca artesanal.

\section{Introdução}

Este artigo tem por objetivo analisar as possibilidades e os desafios para a implementação de projetos de economia solidária entre os pescadores artesanais $^{1}$ do Litoral Fluminense, na região da Bacia de Campos (BC). ${ }^{2}$ Os resultados partem dos trabalhos de campo realizados pelo Projeto de Educação Ambiental (PEA) Pescarte. ${ }^{3}$ Este projeto foi conduzido pela

\footnotetext{
${ }^{1}$ Pescadores artesanais podem ser marítimos, lagunares, continentais e interiores. São divididos pelo porte dos barcos: pequenos (pesca de canoa e individual ou dupla), médios (barcos a motor e até $8 \mathrm{AB}$; e tripulação acima de três pessoas) e grande porte (barcos a motor e acima de $8,1 \mathrm{AB}$ ). ${ }^{2}$ A BC possui atualmente 55 campos de petróleo, com 826 poços exploratórios. Estes poços de petróleo estão vinculados a 45 plataformas marítimas, sendo 41 plataformas de produção e quatro de processamento.

3 O PEA Pescarte é um projeto de mitigação ambiental formulado a partir das condicionantes da Nota Técnica do IBAMA e do Diagnóstico Participativo do PEA-BC. Tem como objetivo a execução de ações de mitigação decorrentes da exploração e produção de petróleo e gás na Bacia de Campos desenvolvida pela Petrobras, tendo como foco as comunidades de pescadores artesanais circunscritas em sete municípios da BC no estado do Rio de Janeiro, Brasil.
} 
Universidade Estadual do Norte Fluminense Darcy Ribeiro (UENF), localizada em Campos dos Goytacazes, principal município da Região Norte do estado do Rio de Janeiro, em parceria com a Petrobras e o Instituto Brasileiro do Meio Ambiente e dos Recursos Naturais Renováveis (IBAMA). Trata-se de um órgão público vinculado ao Ministério do Meio Ambiente do Brasil, cuja atuação ocorre em todo o território nacional, com poder de polícia ambiental, sendo responsável pelo licenciamento, bem como pelo controle e fiscalização sobre a utilização dos recursos naturais no país.

$\mathrm{O}$ alcance da pesquisa e a capacidade de intervenção se projetam em sete municípios da Bacia de Campos: Arraial do Cabo, Cabo Frio, Macaé, Quissamã, Campos dos Goytacazes, São João da Barra e São Francisco do Itabapoana. Trata-se de uma proposta inovadora, considerando o histórico de projetos de educação ambiental ${ }^{4}$ realizados na Bacia de Campos junto às comunidades pesqueiras, quase sempre voltadas à formação cidadã. Por sua vez, o PEA Pescarte visa, além da formação cidadã, uma intervenção social que tem por anseio ampliar a capacidade organizativa dos pescadores por meio do desenvolvimento e implementação de projetos de geração de trabalho e renda. Afinal, a pesca artesanal representa uma atividade econômica significativa para a região. Deste modo, os mecanismos de intervenção social tornam-se especialmente pertinentes e necessários, dada a desarticulação e a precariedade das condições sociais e econômicas de seu público-alvo. Além disso, o projeto transita em um nível muito intenso do cotidiano de vida destas pessoas; discute sonhos e esperanças de um grupo que historicamente tem sofrido com o abandono do Estado e com a ação de projetos desarticulados de sua realidade.

As ações realizadas no campo tiveram uma duração de 24 meses, entre os anos de 2014 e 2016. Do que se observou ao longo deste período do projeto, é legítimo considerar as problemáticas da organização social, produtiva e da economia solidária como sendo os pontos nevrálgicos a serem tratados na implantação dos projetos de geração, trabalho e renda com os pescadores e seus familiares.

O desenvolvimento deste artigo apresenta quatro abordagens empíricas realizadas pela equipe de pesquisa, sendo: (1) a fala dos pescadores e suas famílias, captadas em uma série de reuniões públicas; (2) os grupos focais

\footnotetext{
${ }^{4}$ A Política Nacional de Educação Ambiental, regulada pela Lei n. ${ }^{\circ}$ 9.795/1999, define a educação ambiental como sendo "os processos por meio dos quais o indivíduo e a coletividade constroem valores sociais, conhecimentos, habilidades, atitudes e competências voltadas para a conservação do meio ambiente, bem de uso comum do povo, essencial à sadia qualidade de vida e sua sustentabilidade". Consultado a 16.04.2016, em http://www.mma.gov.br/educacao-ambiental/ politica-de-educacao-ambiental.
} 
realizados com os pescadores e suas famílias; (3) os dados coletados pelo Censo PEA Pescarte, realizado pela equipe de campo; e (4) o seminário sobre economia solidária ocorrido na UENF.

O artigo está dividido nas seguintes seções: na primeira parte trataremos, brevemente, de um apanhado teórico sobre a economia solidária como parte de um processo educativo. Na sequência será apresentada uma caracterização do campo de pesquisa. Em seguida apresentamos os dados referentes às reuniões do PEA Pescarte. A seção seguinte trata das informações provenientes dos grupos focais realizados junto aos pescadores artesanais. E, finalmente, na última seção serão apresentados os principais apontamentos do seminário de economia solidária realizado pelo PEA Pescarte. Os dados quantitativos apresentados ao logo do texto são oriundos dos questionários do Censo PEA Pescarte.

\section{Economia solidária como um processo educativo}

A economia solidária é uma resposta às mudanças ocorridas no mundo do trabalho, como o desemprego, as condições precárias de trabalho, a terceirização, a concentração da renda e o contínuo processo de destruição do meio ambiente (Singer, 2002; Laville e Gaiger, 2009). Neste sentido, relaciona-se aos processos de luta em que os trabalhadores buscam melhorar as suas condições de vida. Não é fruto de uma lei, mas de ações e práticas, que objetivam transformar a realidade social e econômica a partir da organização de trabalhadores no anseio por romper com os processos de exploração do modelo econômico contemporâneo. Apresenta uma concepção de transformação e emancipação social que busca o resgate da dignidade humana e sua liberdade criativa e produtiva. Trata-se, portanto, de uma "emancipação" que realmente estenda seu alcance para uma pluralidade de atores por meio de um "processo de educação popular" (Laville, 2009).

De acordo com Laville e Gaiger (2009), embora possua acepções diferentes de acordo com cada país, o conceito de economia solidária gira em torno da ideia de solidariedade em oposição ao utilitarismo individualista, que é marca preponderante do capitalismo. Tais questões não se distanciam do mundo da pesca, mesmo porque a imposição de políticas neoliberais a essa atividade implica um processo de privatização e desregulamentação do setor, que tende a privilegiar a indústria pesqueira - eficiente economicamente - em detrimento dos pescadores artesanais (Levkoe, Lowitt e Nelson, 2017). Romper com a exploração e a alienação são determinantes neste processo, uma vez que a incorporação do capitalismo no cotidiano dos indivíduos é um de seus aspectos mais dominantes (Singer, 2002). 
Um dos efeitos espúrios deste sistema de acumulação é o fato de que $1 \%$ da população detém mais de $50 \%$ da riqueza mundial, ${ }^{5}$ o que reflete um cenário de injustiça e desigualdade social. Neste sentido, destaca-se a importância de um movimento contra-hegemônico que consolide o que Boaventura Santos chama de "alternativas de produção" (Santos, 2003). Da mesma forma, ganha evidência a aplicabilidade do termo "produzir para viver" (ibidem), sob a ótica de um movimento alternativo de rompimento com a lógica mercantil, na qual podem se estabelecer empreendimentos viáveis e exitosos que tenham potencial para transformar panoramas de exploração social e econômica (Santos, 2002).

A lógica de funcionamento da economia solidária parte do que Gaiger (2008) chama de "virtudes da comunidade de trabalho". Significa a existência de um elemento comunitário, de ação e gestão conjuntas, executadas de forma cooperada e solidária. Com efeito, apresenta resultados tangíveis e com eficácia na operação econômica. Todavia, algumas fragilidades são comuns nos empreendimentos solidários como,

[...] a falta de experiência nos negócios; desconhecimento dos mercados; oferta de produtos e serviços expostos à grande concorrência e sem contarem a seu favor com maior agregação de valor; ausência de estudos de viabilidade; dependência de instituições de apoio. (Gaiger, 2008: 61)

Não é um modelo imune aos problemas, mas eles são de outra ordem, que não a da busca desenfreada pelo lucro. O que se tem é um compilado de desafios que devem ser enfrentados coletivamente, uma vez que o foco destes empreendimentos são as pessoas, suas famílias, suas trajetórias e a qualidade de vida que podem alcançar, ao agirem de forma conjunta.

Em contextos de exploração laboral, como no caso dos pescadores artesanais - cujo resultado do trabalho é apropriado por atravessadores, por frigoríficos que adquirem a produção desse pescado a preços baixos - a organização social para empreendimentos solidários pode partir do reconhecimento de um espírito coletivo, com base em uma racionalidade específica (Gaiger, 2007) no uso dos recursos disponíveis e acionada pelas sociabilidades configuradas nestes territórios e pelas lutas e dificuldades comuns de um cotidiano marcado pela exploração. Claramente, existe uma identificação entre as famílias de pescadores artesanais, bem como o reconhecimento de que há muito mais em comum do que possíveis divergências.

\footnotetext{
${ }_{5}$ Consultado a 13.10.2016, em https://www.oxfam.org/sites/www.oxfam.org/files/file_attachments/ bp210-economy-one-percent-tax-havens-180116-en_0.pdf.
} 
Este reconhecimento alimenta as ações do PEA Pescarte e aponta para as possibilidades de ações conjuntas.

Cabe ressaltar que, durante os trabalhos da equipe de campo, ficaram evidentes os pontos comuns nos discursos dos pescadores artesanais e a certeza evidente de que, apesar das divergências, eles possuem uma forte identificação de classe que possibilita um reconhecimento conjunto de exploração econômica de que são alvo.

Diante das precariedades que vivenciam os pescadores artesanais, são cada vez mais frequentes ações e estudos que apontam para as potencialidades do fortalecimento de seus processos de organização econômica, social e política, principalmente, por meio das diretrizes da economia solidária. Como assinalam Alves e Salomão (2012), a busca pelo sucesso dos empreendimentos coletivos de base solidária requer que se reconheçam as dinâmicas locais, cujas características implicam em mudanças que devem ser redimensionadas no tempo e podem gerar novas relações sociais e econômicas.

Outro desafio ao empreender projetos que contemplem diferentes comunidades e municípios - como no caso do PEA Pescarte - é analisar suas peculiaridades configuradas pelo local de pesca, se marítimo, interior ou continental e com diferentes artes de pesca, de espécies capturadas, de organização da produção, dentre outros fatores.

Contudo, os empreendimentos solidários entre pescadores artesanais têm o potencial de funcionar como importantes ferramentas de inclusão social e econômica destes sujeitos e de suas famílias e dependem, não somente de acertos econômicos, mas também da organização social, política, técnica e gerencial (Maldonado e Santos, 2006).

Assim, estes processos passam pela consolidação dos conceitos de autogestão, democracia e solidariedade, visando aspectos que vão da técnica à gestão. E, pelo fato de a pesca artesanal estar intimamente ligada ao regime de economia familiar, o envolvimento de toda a família nestes empreendimentos acaba sendo um diferencial importante. Por sua vez, a economia solidária se constitui enquanto processo formativo e educativo contrário à lógica neoliberal, sendo pautado nos princípios da conscientização quanto a exploração do sistema capitalista (Coraggio, 2016). Significa, assim, dizer que valores como a cooperação, a articulação produtiva e a solidariedade são consolidados em um processo de aprendizagem coletiva, dinâmica, na qual os sujeitos deste processo se tornam protagonistas. Como um processo educativo, a economia solidária objetiva consolidar uma nova forma de se produzir, ligada a contextos e práticas sociais e comunitárias, pautadas na busca do bem coletivo, rompendo com a lógica individualista comum ao capitalismo (Santos, 2003). 
Neste contexto, o PEA Pescarte desenvolveu uma série de ações educativas junto aos pescadores e seus familiares por meio de oficinas e cursos sobre a economia solidária e sua importância para a organização social e produtiva. $\mathrm{O}$ objetivo destes momentos se ateve à construção coletiva do conhecimento, entendendo que qualquer projeto a ser articulado futuramente deveria partir do trabalho coletivo e de iniciativas que tivessem correspondência com as necessidades dos pescadores e de seus familiares.

De fato, há que se propor inovações, em que novas práticas sociais e o desenvolvimento de uma tecnologia social, que tenha como base a economia e a educação popular, possam ser vistas como soluções criadas a partir de necessidades sociais, expressas de maneira focalizada em cada contexto social e político no qual são implementadas. Portanto, falamos muito mais de um processo metodológico do que da aplicação de uma fórmula. Neste sentido, as novas tecnologias sociais se valem das realidades locais que, conjugadas com formas de organização coletiva, podem propiciar a inclusão social e a melhoria da qualidade de vida, a partir da geração de trabalho e renda. Essa tecnologia se materializa em produtos, técnicas ou metodologias que possam ser replicáveis, sendo desenvolvidas com base no saber local com a interação dos grupos sociais (Lassance Júnior e Pedreira, 2004).

Isso na contramão do modelo vigente de desenvolvimento, com base nas relações sociais com as quais se torna possível a apropriação de técnicas e metodologias capazes de criar ambientes institucionais favoráveis, seja com novas leis, novos padrões de financiamento e custeio, apropriação e transferência de conhecimentos e técnicas, pode abrir novas oportunidades de inclusão social (Caccia Bava, 2004). Tais apontamentos se vinculam à necessidade de associação entre uma gestão democrática e a viabilidade econômica, aliando valores solidários à capacidade de manutenção e competitividade do empreendimento.

As seções que se seguem referem-se à pesquisa de campo e ao estudo propriamente dito. São os resultados do que se avançou junto aos pescadores artesanais da Bacia de Campos em meio a potencialidades enormes de trabalhos solidários. Mas, de início, há que se apresentar ao leitor o universo da pesquisa realizada pelo PEA Pescarte.

\section{Caracterização do campo de pesquisa}

A área geografia da Bacia de Campos concentra a maior parte dos investimentos, estatais e privados, no segmento petrolífero, justamente por ser o maior reservatório de petróleo e gás do Brasil, correspondendo a mais de 
$80 \%$ de toda a produção offshore ${ }^{6}$ A liderança neste ambiente empresarial competitivo cabe à Petrobras, que divide espaço com seis grandes corporações privadas do setor petrolífero: a PetroRio (antiga HRT Participações), a OGPar Óleo e Gás Participações, a Chevron Corporation Brasil, a Shell Brasil, OGX, e a Statoil. Todas são compostas por capital estrangeiro, sendo as duas primeiras consórcios que contam com capital nacional.

É neste ambiente complexo e de alta competitividade que estas grandes corporações convivem com as comunidades pesqueiras. Atuam nas plataformas offshore, a cerca de $100 \mathrm{~km}$ da costa, mas impactam a atividade pesqueira de forma direta.

O Estado, por meio da Coordenação Geral de Petróleo e Gás (CGPEG), órgão do IBAMA, atua no sentido de licenciar, regular e controlar a exploração desses recursos energéticos e, como parte de suas funções, exige a implementação de programas de mitigação ambiental, ${ }^{7}$ normalmente, desenvolvidos como projetos de educação ambiental. Uma importante questão, aqui considerada, diz respeito ao termo "educação ambiental" que é utilizado pela legislação brasileira. Afinal, quem deve ser "educado ambientalmente", as companhias extratoras de petróleo, a quem os pescadores atribuem a responsabilidade pela situação vivida, ou aos próprios pescadores? $\mathrm{Na}$ intenção da lei, ambos seriam igualmente atingidos pelos processos educacionais ambientais. Contudo, sabe-se que é mais fácil educar ambientalmente os atingidos pelos impactos dos que os seus perpetradores, pois, como se observou ao longo da pesquisa, os mecanismos de controle e monitoramento das ações empresariais ainda são precários e, em grande medida, são as próprias empresas poluidoras as responsáveis pelo monitoramento de sua ação impactante. ${ }^{8}$

As comunidades de pescadores artesanais, por serem destacadamente os mais impactados por essas atividades, são assim o público-alvo de uma série de projetos coordenados por essas empresas como forma de mitigação ambiental (Campos; Timóteo e Silva, 2015). A Figura 1 destaca os projetos vigentes na Bacia de Campos.

\footnotetext{
${ }^{6}$ As plataformas de extração de petróleo podem ser no continente, em terra firme, denominadas de "plataformas onshore" ou no mar, sendo chamadas "plataformas offshore", com uma estrutura moderna de perfuração em alto mar, abrigando trabalhadores e equipamentos necessários na perfuração de poços, além da extração de petróleo e gás. Tais plataformas podem ser fixas no solo marinho ou flutuantes.

${ }^{7}$ Os planos de mitigação ambiental referem-se a medidas que visam reduzir os impactos causados no meio ambiente por empreendimentos econômicos que afetem as chamadas "zonas naturais", bem como aquelas populações que vivem nessas localidades.

${ }^{8}$ Consultado a 08.02.2018, em https://www.em.com.br/app/noticia/internacional/2018/02/05/ interna_internacional,936027/petrobras-multada-por-minimizar-dados-de-poluicao-marinha.shtml.
} 


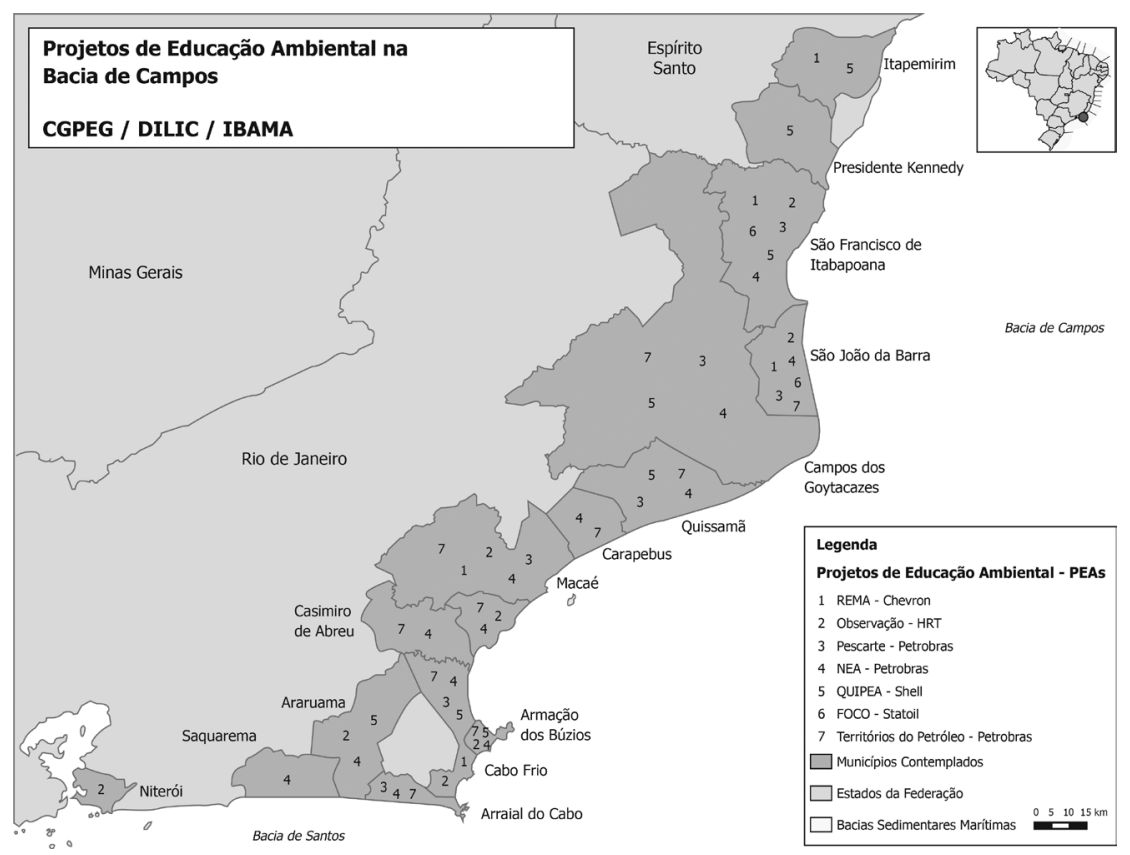

\section{FIGURA 1 - Mapa dos Projetos de Educação Ambiental na Bacia de Campos}

Fonte: Adaptado pelos autores a partir do Programa de Educação Ambiental da Bacia de Campos, PEA-BC. ${ }^{9}$

O recorte espacial da pesquisa refere-se aos municípios selecionados com base na importância relativa que a atividade pesqueira exerce na ocupação de mão de obra local e por serem os mais atingidos pelos empreendimentos desenvolvidos pelas empresas petroleiras, conforme apontado pelo Plano de Caracterização Regional da Bacia de Campos (PCR-BC). ${ }^{10}$ É nesse ambiente que se insere este estudo e é a partir daí que se busca visualizar as iniciativas produtivas e de organização social que permitiram que os pescadores artesanais pudessem desenvolver empreendimentos solidários tendo como base a cadeia pesqueira da Bacia de Campos e uma transformação desta realidade social marcada por pobreza e exploração.

\footnotetext{
${ }^{9}$ Consultado a 25.05.2018, em http://pea-bc.ibp.org.br/index.php?view=projeto-selecao.

${ }^{10}$ Consultado a 08.08.2015, em http://licenciamento.ibama.gov.br/Petroleo/Temas\%20Especiais/ PCR-BC/SIG\%20-\%20Parte\%201/HAB_MAPA_BASE/DICIONARIO_DADOS_HAB_ MAPA_BASE.pdf.
} 


\section{Conhecendo o campo: as reuniões do PEA Pescarte}

As informações tratadas nesta seção referem-se aos resultados das reuniões para apresentação do Projeto PEA Pescarte, realizadas ao longo de 2014, junto com as lideranças das colônias ${ }^{11}$ e de associações de pescadores artesanais; posteriormente, foram realizadas reuniões junto a estas comunidades de pescadores e pescadoras artesanais dos sete municípios pesquisados. Os encontros foram realizados para apresentar o projeto aos pescadores e tentar romper a desconfiança destas pessoas frente "a mais um projeto". Essa fala ressalta uma insatisfação recorrente, por parte dos pescadores, relativa à quantidade de projetos desenvolvidos pelas empresas do setor de petróleo e gás na região e a pouca efetividade que apresentam no cotidiano desse grupo social.

As reuniões foram conduzidas pelos pesquisadores do PEA Pescarte e contaram com a presença das principais lideranças entre os pescadores e das instituições de representação dos seus interesses. Os encontros deixaram clara a existência de uma "descrença" em relação aos projetos de mitigação que circulam pelas comunidades, pois, na opinião dos presentes nas reuniões, os projetos de mitigação ambiental não se dirigem aos reais problemas enfrentados por essa categoria de produtores.

Assim, muitos destes projetos falham ao não dialogar com os pescadores. São projetos elaborados, na sua maioria, sem a participação das comunidades pesqueiras. A partir dessa dosagem de aprendizado, o PEA Pescarte partiu de uma outra lógica, de modo a propor soluções dialogadas aos problemas dessas comunidades. Tais iniciativas foram possíveis ouvindo e observando as suas realidades, em uma série de reuniões e um intenso trabalho de campo que acabou por estabelecer laços com estas comunidades. Nas reuniões realizadas, uma avalanche de problemas foi apontada pelos pescadores. Entre as reais dificuldades enfrentadas por estes produtores foi apontada a deterioração e flutuação dos preços de seus produtos. A fala de um pescador ilustra bem esta situação,

Já devem ter falado com o senhor, em alguma reunião, que o pescador tá cansado de conversa, de papel. [...] Porque hoje, essa semana mesmo, o cara levantou de 10 a 15 toneladas de peixe e vendeu a 2,00 $\mathrm{R} \$$ passou para 3,00 $\mathrm{R} \$$ e agora tá de $1,00 \mathrm{R} \$$ a $1,50 \mathrm{R} \$$. Agora começou a safra do dourado que estava $12,00 \mathrm{R} \$$

${ }_{11}$ As colônias são o equivalente ao sindicato de trabalhadores; e são reconhecidas pela Lei Federal 11.699, de 13 de junho de 2008. Consultado a 01.12.2017, em http://www.planalto.gov. br/ccivil_03/_ato2007-2010/2008/lei/111699.htm. 
e agora veio para $10,00 \mathrm{R} \$$, veio para $9,00 \mathrm{R} \$$, veio para $8,00 \mathrm{R} \$$ e agora tá $8,50 \mathrm{R} \$ .{ }^{12}$ A tendência é cair! ${ }^{13}$

Outra dificuldade destacada foi a falta de confiança, por parte dos pescadores artesanais, com a coordenação de projetos apresentados pelas companhias que atuam na exploração de petróleo e gás na região, como medidas de compensação por danos ambientais. A ausência de decisões coletivas, que levassem em conta as opiniões e desejos dos pescadores, foi um dos principais problemas destacados, apontado ainda como um dos motivos dos fracassos destas iniciativas, percebidas em experiências anteriores. Como ressaltou um pescador ao dizer que "num projeto coletivo, manter os pés atrás é a atitude mais correta porque já aconteceram muitos erros, já foi feita muita coisa errada". A busca pelo desenvolvimento comunitário por meio de projetos de geração de trabalho e renda não é simples, pois esbarra nas "dificuldades de investimentos e incentivos voltados para a pesca”. Em outras palavras, foi apontada a falta de debates mais amplos com as comunidades pesqueiras sobre a condução desses projetos e a conexão com a realidade de suas vidas.

Nesse rol de problemas, há também "a perda de pesqueiros e de espaços para a atividade da pesca para a instalação de empreendimentos em locais tradicionais em que se pescava antigamente".${ }^{14}$ Tanto nas reuniões como nos grupos focais, houve o alerta recorrente dos pescadores quanto a "escassez do pescado". ${ }^{15}$ É recorrente nas falas desses trabalhadores o conflito pelo espaço marítimo, uma vez que "as plataformas tiram todos os espaços para pesca, como agora, com a sísmica" ${ }^{16}$ Isso ocorre porque, como evidenciado por um pescador, "o navio de sísmica, que entra no zoneamento de milhas, onde tem os melhores pesqueiros, afeta a captura do peixe, pois o navio dá um choque na água, podendo ser sentido no barco, mesmo a grandes

\footnotetext{
${ }_{12}$ A cotação média entre as moedas Real $(\mathrm{R} \$)$ em relação ao Euro $(€)$, para o mês de outubro de 2014, foi de $1,00 €$ para $3,10 \mathrm{R} \$$.

${ }_{13}$ Reunião realizada com as lideranças em Campos dos Goytacazes, em outubro de 2014.

${ }^{14}$ Fala proferida por um dos pescadores presentes na reunião realizada com as lideranças da pesca em São Francisco do Itabapoana, em outubro de 2014.

${ }^{15}$ Cada vez que o tema relacionado à ausência do pescado aparecia nas reuniões, o coordenador do PEA Pescarte, o professor Geraldo Márcio Timóteo, ressaltava que "[...] não é necessário o aumento da quantidade de pescado, pois não adiantará aumentarmos o volume, se não soubermos administrar a safra pescada. Portanto, passa pela organização social dos pescadores e pescadoras. Esse é o maior desafio".

${ }^{16}$ A sísmica é uma atividade técnica que consiste no uso de equipamentos para análises que podem identificar a presença de petróleo no subsolo marinho. Esses equipamentos produzem ondas que penetram o subsolo e são refletidas de volta, permitindo identificar a presença de minerais naquela área. Consultado a 11.03.2016, em https://www.comunicabaciadesantos.com.br/noticia/petrobrasinicia-pesquisa-sismica-maritima-no-bloco-de-libra.html.
} 
distâncias" ${ }^{17}$ São interferências claras da exploração de petróleo offshore, mas que não se limitam a essa atividade. A pesca industrial também compromete o estoque pesqueiro, pois, conforme ressaltado, é ela que "pega os maiores peixes deixando apenas os pequenos". ${ }^{18}$ Assim, o problema relativo à diminuição dos estoques pesqueiros, conforme relatado pelos pescadores, se soma àqueles identificados nos meios tradicionais de comercialização do pescado, que é feito por intermédio dos chamados de "atravessadores". Tais questões se refletem na instabilidade da renda destes trabalhadores. Trata-se de uma reclamação constante, trazida à baila nas conversas, em qualquer localidade que a equipe do projeto tenha percorrido.

Neste sentido, a cadeia da pesca artesanal merece ser pensada com mais cautela, uma vez que a diferença entre o valor pago ao pescador e o preço ao consumidor final é exorbitante. Com efeito, a Organização das Nações Unidas para a Alimentação e a Agricultura (FAO), aponta como uma possível solução a noção de "circuitos curtos", como uma forma de comércio baseada na venda direta de produtos frescos, como o pescado, o que significa a eliminação ou retração das atividades dos intermediários (FAO, 2015). Trata-se da busca de novas formas de acesso ao mercado, com destaque para esses canais de comercialização, por meio de cadeias curtas em que se valorizam a identificação do produto e do produtor, dando respaldo à qualidade e aos aspectos locais (Cunha, 2015). Estas unidades de pequena produção, nas quais se encontram os pescadores artesanais, se destacam também por apresentarem um impacto ecológico bem menor, comparado à pesca industrial, pois não agravam as chamadas "crises de sobre-pesca e degradação” no espaço pesqueiro (Levkoe; Lowitt e Nelson, 2017: 65). São, portanto, possibilidades com as quais os pescadores artesanais se deparam, mas que não se efetivam de forma particularizada. Dependem, sobretudo, de organização social. Ou seja, de pouco adianta pescar uma quantidade maior, considerando que o valor pago aos pescadores é ínfimo. Isso não faz com que a relação comercial mude e o valor justo fique com os pescadores. Como um deles indica, "A riqueza que passa na mão dos pescadores vai para o bolso de outro". ${ }^{19}$

O caminho percorrido pelo pescado até a mesa do consumidor final é longo. Contudo, há oportunidades para se agregar valor, fazendo com que a renda do pescador aumente. As falas apontam para "alternativas de

\footnotetext{
${ }_{17}$ Reunião realizada com as lideranças da pesca em São Francisco do Itabapoana, em outubro de 2014.

${ }^{18}$ Fala proferida por um dos líderes dos pescadores da Lagoa de Cima, em reunião realizada com as lideranças em Campos dos Goytacazes, em outubro de 2014.

${ }_{19}$ Fala proferida por um pescador marítimo em reunião com lideranças na comunidade pesqueira do Farol de São Thomé, em Campos dos Goytacazes, em novembro de 2014.
} 
desenvolver ações de geração de trabalho e renda por meio da organização social, sendo que para os pescadores conseguirem obter unidades produtivas é necessário fortalecer a organização social". ${ }^{20}$

Como apontado nas reuniões, a pesca "tem que fazer efeito no bolso do pescador, tem que gerar renda", pois "tudo o que eles querem é pescar". Desse modo, a mobilização social é essencial para a geração de trabalho e renda, de modo a romper com o ciclo vicioso em que aqueles que comercializam o produto ganham mais do que aqueles que o produzem. A organização social e produtiva pode tornar a pesca mais atrativa ao fazer com que se consiga obter maior renda com atividade. De contrário, não será possível fortalecer a categoria e reverter o processo de afastamento "de jovens da pesca, podendo, em um futuro próximo, haver pescado, mas não mais pescador" ${ }^{21}$ Neste sentido, como apontaram os participantes das reuniões "é importante o resgate da identidade do pescador". ${ }^{22}$ Trata-se, portanto, de um desafio maior para uma categoria que tem uma organização ainda frágil.

Quando se fala em

organizar pessoas, de ajudar, de somar esforços, talvez estejamos colocando a coisa mais difícil de acontecer. Encher um local de máquinas é só ter dinheiro, agora fazer dar certo, fazer com que as pessoas trabalhem juntas, esse é o desafio: gerar confiança social suficiente para que possam trabalhar juntos. ${ }^{23}$

Vale ressaltar que por "confiança" consideramos a convicção dos indivíduos sobre o comportamento esperado do outro. Ou de outra forma, podemos dizer que confiança é a capacidade de acreditar que uma pessoa, ou um grupo de pessoas, agirá de uma maneira esperada ou anunciada. E este é um dos pilares da economia solidária. Ter confiança é, ainda que temporariamente, suspender as incertezas sobre as ações dos outros. E isso só poderá ser desenvolvido quando houver o fortalecimento da organização comunitária, podendo, de fato, vir a se tornar uma alternativa aos meios usuais de comercialização da produção pesqueira local.

As reuniões mostraram que o elemento da desconfiança tinha várias faces entre os pescadores artesanais, como a falta de credibilidade em relação aos projetos de mitigação de impactos, capitaneados pela Petrobras, IBAMA

\footnotetext{
${ }^{20}$ Fala proferida por um pescador que exerce liderança nas comunidades de Parque dos Prazeres e Vigário, em Campos dos Goytacazes, em reunião no mês de novembro de 2014.

${ }^{21}$ Fala proferida por um pescador que exerce liderança nas comunidades de Parque dos Prazeres e Vigário, em Campos dos Goytacazes, em reunião no mês de novembro de 2014.

${ }^{22}$ Reunião realizada com as lideranças de Cabo Frio, em outubro de 2014.

${ }^{23}$ Fala proferida por um pescador marítimo, na reunião com lideranças na comunidade pesqueira do Farol de São Thomé, em Campos dos Goytacazes, em novembro de 2014.
} 
e Instituto Estadual do Ambiente (INEA), ${ }^{24}$ a descrença com o poder público e com as entidades representativas, como as colônias e associações de pesca, ${ }^{25}$ além da própria falta de confiança presente entre os pescadores. A Tabela 1 traz apontamentos relativos à confiança dos pescadores, contida no Censo PEA Pescarte. Nessa abordagem, os entrevistados são questionados sobre em quem eles confiam em cada comunidade. Os resultados apontam um elevado grau de "desconfiança" de uma maneira geral, tendo como extremos os municípios de Campos dos Goytacazes e Cabo Frio.

TABELA 1 - Qual a pessoa que você mais confia na comunidade (em \%)?

\begin{tabular}{|c|c|c|c|c|c|c|c|c|}
\hline & 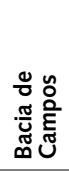 & 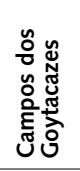 & $\begin{array}{l}\stackrel{\mathbb{J}}{\Xi} \\
\sum^{\pi}\end{array}$ & 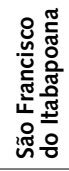 & 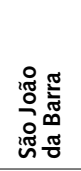 & 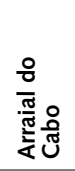 & 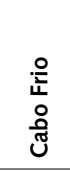 & 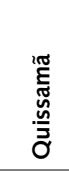 \\
\hline $\begin{array}{l}\text { Não indicaram } \\
\text { ninguém }\end{array}$ & 58,5 & 68,6 & 61,9 & 63,4 & 46,6 & 61,1 & 44,7 & 59,3 \\
\hline Indicaram 1 pessoa & 22,5 & 15,0 & 20,9 & 23,9 & 21,4 & 23,5 & 31,9 & 11,3 \\
\hline $\begin{array}{l}\text { Indicaram } 2 \\
\text { pessoas }\end{array}$ & 11,3 & 10,6 & 10,3 & 7,7 & 15,2 & 9,7 & 16,8 & 12,0 \\
\hline $\begin{array}{l}\text { Indicaram } 3 \\
\text { pessoas }\end{array}$ & 5,3 & 4,9 & 5,3 & 4,0 & 7,9 & 3,6 & 4,6 & 15,3 \\
\hline $\begin{array}{l}\text { Indicaram } 4 \\
\text { pessoas }\end{array}$ & 1,2 & 0,5 & 1,0 & 0,9 & 3,1 & 0,8 & 1,3 & 1,3 \\
\hline $\begin{array}{l}\text { Indicaram } 5 \\
\text { pessoas }\end{array}$ & 1,2 & 0,3 & 0,7 & 0,0 & 5,8 & 1,3 & 0,7 & 0,7 \\
\hline
\end{tabular}

Fonte: Questionário Censo PEA Pescarte, 2015.

Os dados evidenciam que quase $60 \%$ dos entrevistados não apontaram ninguém em quem confiam. Ou seja, temos um ambiente, à primeira vista, pouco propício a cooperação. Mas, ao mesmo tempo, as entrevistas

${ }^{24}$ O INEA é um órgão do governo do estado do Rio de Janeiro, que tem na administração pública a função de formular e coordenar a política estadual de proteção e conservação do meio ambiente. Atua no controle e fiscalização ambiental do estado.

${ }^{25}$ De acordo com a Lei n. ${ }^{\circ}$ 11.699/2008, "as colônias de pescadores, as federações estaduais e a confederação nacional dos pescadores ficam reconhecidas como órgãos de classe dos trabalhadores do setor artesanal da pesca, com forma e natureza jurídica próprias, obedecendo ao princípio da livre organização". As primeiras colônias de pescadores foram fundadas, no Brasil, em 1919, sendo consideradas à época como instituições estratégicas de defesa nacional pela Marinha de Guerra do Brasil, sendo que o primeiro estatuto das colônias foi de 1923 (Garcez e Sánches-Botero, 2005). 
mostraram que eles reconhecem o caminho da cooperação e organização social como o único meio para que possam fortalecer a categoria, mas que não possuem ainda os meios para colocar isso em prática. Há que se ressaltar, porém, os limites impostos pelo próprio formato da pesquisa, ao tratar de um tema complexo de se mensurar. O termo confiança, dada a sua sensibilidade de percepção, suscita uma combinação de variáveis que podem influenciar diretamente os resultados. O que se pode dizer, no entanto, é que, para essa pesquisa efetuada com os pescadores artesanais desses municípios, os dados da pesquisa sobre confiança ressaltam o que foi observado no campo, a partir das técnicas adotadas.

No entanto, apesar dos desafios a serem enfrentados, se percebe alguma convergência para os princípios da economia solidária e a possibilidade real de uma ação efetiva em direção a uma maior organização social. Em outras palavras, as reuniões com lideranças das comunidades de pescadores artesanais, dos sete municípios analisados, apesar de não apresentarem uma organização social definida, apontam, sem exceção, que a saída para a pesca artesanal e, por consequência, para as famílias de pescadores, é o trabalho coletivo. Tal argumento foi uníssono em todas as reuniões. E a alternativa apontada, em grande parte das reuniões, foi a criação de uma cooperativa ou a reformulação daquelas já existentes. Sobre esse aspecto, foi ressaltado em algumas falas que "já tiveram iniciativas na região como cooperativa, mas não houve sucesso por falta de mobilização". ${ }^{26}$ Tais questões que refletem essa baixa aderência dos pescadores possuem um conjunto amplo de causas. Como ressaltado pelos pescadores, há um enorme descrédito com a própria Petrobras se as demais empresas que atuam nesse segmento de petróleo e gás, como sendo capazes de propiciar alguma solução relativa ao problema enfrentado por eles, seja no que diz respeito à dependência financeira dos atravessadores ou na escassez do pescado, duas das principais reclamações dos pescadores artesanais da região. Para além desses apontamentos, evidenciou-se em algumas oportunidades, nas falas desses trabalhadores, também o descrédito com algumas lideranças, no que se refere a falta de preparo para a gestão destes empreendimentos e a baixa adesão da categoria.

Vale ressaltar que tais empreendimentos, segundo Gaiger (2013) tornam-se possíveis quando as lideranças assumem um papel de protagonismo social, dada sua capacidade de expandir os laços de confiança e respeito. Em muitas reuniões de pauta aberta realizadas com as comunidades, esse protagonismo das lideranças não se observou, de fato. Ao contrário.

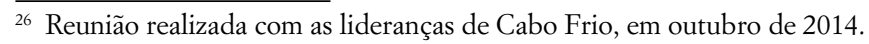


Ocorreram situações em que essas lideranças impunham uma posição desfavorável aos propósitos e métodos adotados pelo PEA Pescarte. Tal posicionamento dessas lideranças, por sua vez, teve como reflexo imediato a inibição, no que se refere às iniciativas de participação de muitos pescadores nessas reuniões. São questões que reforçam as dificuldades no que respeita à organização social entre esses trabalhadores, que mesmo cientes de maiores chances de ganhos conjuntos, ainda assim, revelam que o elemento da desconfiança exerce um papel determinante nas suas ações.

Há, ainda, uma questão da prática e dos papéis exercidos dentro da cadeia da pesca artesanal, mais claramente entre a produção e o beneficiamento, como foi apontado em uma reunião: "o pescador não vai chegar do mar e limpar peixe cansado. Quem vai ficar com esse pescado? A colônia de pescadores vai ficar com o pescado dos pescadores? Pescador é pescador, e feirante é feirante". ${ }^{27}$

No que se refere à participação das mulheres nas reuniões com os pesquisadores, elas se mostraram mais entusiastas com as possibilidades de participarem de empreendimentos sociais, especialmente no que se refere ao beneficiamento do pescado. Isso porque há uma restrição da atuação das mulheres na pesca, sobressaindo a reciclagem e o artesanato, que são as iniciativas mais recorrentes entre as esposas e filhas de pescadores. Uma esposa de pescador foi contundente ao declarar:

Eu sozinha lutava com o projeto há dez anos sempre pedindo ajuda e a colônia me ajudou. [...] Cheguei lá na Barra, na casa de uma senhora e ela estava descascando camarão. Tinha um balde assim [apontando o tamanho do balde] de cabeça de camarão. Eu disse: você pode me dar isso daqui? Você vai fazer o quê? Eu disse: eu vou reciclar e vou criar a culinária e vou trazer para você ver. Então com a casca do camarão eu criei uma farinha que ela é utilizada hoje para fazer salgados, pode fazer lanches, pode fazer tudo. Com a cabeça do peixe, que eu acabei agora, semana passada, de fazer uma sopa para as pequenas creches e para os colégios, para famílias carentes. Já faço a distribuição de outras coisas por fora. ${ }^{28}$

Ela continuou dizendo que é uma forma de geração de trabalho e renda com "subprodutos do peixe, cursos de recuperação do pescado, porém em pequena escala, porque sozinha não consigo atender as demandas". Ressaltou que "são produtos que têm mercado e procura". Nesse sentido,

${ }^{27}$ Fala proferida por um pescador de águas continentais na reunião realizada com as lideranças de Campos dos Goytacazes, em outubro de 2014.

${ }^{28}$ Reunião realizada com as lideranças de Campos dos Goytacazes, em outubro de 2014. 
o protagonismo destas mulheres pode romper com processos de "invisibilidade feminina" na pesca artesanal.

\section{Os grupos focais realizados pelo PEA Pescarte}

Em uma segunda etapa da pesquisa a construção dos dados se deu por meio de grupos focais, realizados nos sete municípios analisados e segregados por homens, mulheres e jovens (com idade entre 16 e 21 anos). Assim, foram realizados quatro grupos focais em cada município, sendo um de homens, um de mulheres, um de jovens e um grupo misto. Os grupos focais representaram a possibilidade de uma discussão mais aprofundada e mediada pelo coletivo formado na seleção dos participantes. Foram tratados pontos referentes à renda e ao mercado; à organização social e às expectativas em relação com os projetos de mitigação ambiental. Discussões relacionadas a esses temas foram estimuladas pelos mediadores de cada grupo focal, sendo estes pesquisadores do PEA Pescarte. O intento foi fomentar debates entre os participantes, em cada um dos estratos, sobre as suas posições em relação aos temas definidos na condução dos grupos focais. A Tabela 2 traz um resumo dos participantes dos grupos focais realizados.

TABELA 2 - Número de participantes dos grupos focais

\begin{tabular}{|c|c|c|c|c|c|c|}
\hline \multirow{2}{*}{ Município } & \multirow{2}{*}{$\begin{array}{c}\text { Grupo } \\
\text { focal } \\
\text { Homens }\end{array}$} & \multirow{2}{*}{$\begin{array}{c}\text { Grupo } \\
\text { focal } \\
\text { Mulheres }\end{array}$} & \multirow{2}{*}{$\begin{array}{c}\text { Grupo } \\
\text { focal } \\
\text { Jovens }\end{array}$} & \multicolumn{3}{|c|}{$\begin{array}{l}\text { Grupo focal } \\
\text { Misto }\end{array}$} \\
\hline & & & & Homens & Mulheres & Jovens \\
\hline Quissamã & 8 & 7 & 6 & 3 & 6 & 0 \\
\hline $\begin{array}{l}\text { São Francisco de } \\
\text { Itabapoana }\end{array}$ & 10 & 11 & 5 & 4 & 5 & 3 \\
\hline $\begin{array}{l}\text { Campos dos } \\
\text { Goytacazes }\end{array}$ & 5 & 10 & 7 & 3 & 4 & 5 \\
\hline Macaé & 10 & 0 & 0 & 3 & 5 & 2 \\
\hline São João da Barra & 6 & 7 & 14 & 4 & 4 & 2 \\
\hline Arraial do Cabo & 18 & 5 & 0 & 6 & 6 & 0 \\
\hline Cabo Frio & 7 & 4 & 0 & 6 & 3 & 1 \\
\hline Total & 64 & 44 & 32 & & 75 & \\
\hline
\end{tabular}

Fonte: Listas de presença do PEA Pescarte. 
Em todos os grupos realizados houve grande ênfase dos participantes no que diz respeito à rotina árdua, em que se destacam as dificuldades e imprevisibilidades presentes no desenvolvimento da atividade pesqueira, assim como as incertezas geradas pela diminuição do pescado e o aumento do esforço para manter a renda mínima da família. Sobre esse aspecto, um elemento que se destacou nos diversos grupos focais realizados foi a insuficiência da renda retirada do ofício da pesca. Ou seja, viver exclusivamente com a renda da pesca é uma tarefa difícil. Essa questão é apontada como sendo uma das razões para que a família pescadora não queira que seus filhos sigam a profissão. Trata-se de uma opinião que foi compartilhada por quase todos os pescadores nos grupos focais realizados. Inclusive, os jovens participantes dos grupos focais disseram que eles próprios não têm interesse em trabalhar com a pesca, tendo em vista a baixa perspectiva de renda. Essa questão também foi perguntada no questionário do Censo PEA Pescarte, cujos resultados podem ser observados na Tabela 3, a qual aponta que mais de $85 \%$ dos pescadores disseram que não gostariam que os seus filhos seguissem a sua profissão.

TABELA 3 - Gostaria que seus filhos trabalhassem na pesca?

\begin{tabular}{|c|c|c|c|c|c|}
\hline & & Frequência & Porcentual & $\begin{array}{l}\text { Porcentagem } \\
\text { válida }\end{array}$ & $\begin{array}{l}\text { Porcentagem } \\
\text { acumulativa }\end{array}$ \\
\hline \multirow{3}{*}{ Válido } & Não & 2963 & 29,4 & 85,2 & 85,2 \\
\hline & Sim & 515 & 5,1 & 14,8 & 100,0 \\
\hline & Total & 3478 & 34,5 & 100,0 & - \\
\hline \multirow{4}{*}{ Ausente } & Não se aplica & 6447 & 63,9 & - & - \\
\hline & Não respondeu & 86 & 0,9 & - & - \\
\hline & Não sabe & 71 & 0,7 & - & - \\
\hline & Total & 6604 & 65,5 & - & - \\
\hline Total & & 10082 & 100,0 & - & - \\
\hline
\end{tabular}

Fonte: Questionário Censo PEA Pescarte, 2015.

Em termos operacionais, no que se refere ao entendimento desse instrumento analítico que é o Censo PEA Pescarte, no total foram realizadas 3474 entrevistas primárias (a pescadores) e coletadas informações secundárias de 
10082 indivíduos (membros das famílias de pescadores). Os respondentes principais foram os indivíduos ligados diretamente à cadeia da pesca. Não foram considerados para essa base de dados pessoas que não exerciam atividades relacionadas à pesca. Entre estes chamados no questionário de "ausentes", tem-se familiares, como esposas e filhos residentes na casa, mas que não atuavam na pesca. Também foram desconsiderados os atravessadores, comerciantes de pescados e donos de embarcações, mas que não pescam - apenas locam os barcos. A base de dados do Censo PEA Pescarte considerou todos estes indivíduos.

A continuidade da profissão de pescador artesanal por parte dos jovens também foi tema abordado nos grupos. Um dos presentes fala que é filho de pescador, mas não pretende seguir na profissão, dadas as dificuldades que seu pai passa para pescar atualmente. Outro elemento referido é o valor do pescado e sua constante desvalorização na relação com os diferentes integrantes na cadeia produtiva da pesca: "sempre que meu pai volta, ele acaba ficando mais pobre do que quando saiu. Ele sai com o pescado num preço e volta e vende pela metade". A fala reflete a situação vivida pelos pescadores e percebida pelos seus filhos, o que reforça o risco da continuidade dessa profissão.

A questão da insuficiência de renda foi um tema recorrente nas conversas, como já ressaltado anteriormente, e que tem levado os pescadores artesanais a conjugarem este ofício com outras formas de ganhos financeiros para sua sobrevivência e de sua família. Essas funções vão da agricultura à construção civil. Essa ocorrência é mais nítida nos pescadores de águas continentais.

O que se pode destacar é que os pescadores, ao entrarem no mercado de trabalho fora da pesca, o fazem pela base da pirâmide funcional, elemento esse que caracteriza o processo de migração entre ocupações, nas quais quanto mais baixa a hierarquia funcional de origem, mais baixa será a sua inserção no mercado de trabalho de destino (Ramires, Molina e Hanazaki, 2007; Capellesso e Cazella, 2011). Como bem ressaltou outra participante, "nem sempre tem renda, não sabe se volta. Não tem um segundo plano e sem opção de escolha. Além de ter uma insegurança grande, quando vem a 'abertura da pesca' a gente nunca sabe se vai haver peixe".

Uma outra questão é que o exercício de uma outra função fora da área da pesca faz com que esses indivíduos percam a sua condição de segurado especial do Instituto Nacional de Seguridade Social (INSS), ${ }^{29}$

\footnotetext{
${ }^{29}$ Segurados especiais são os trabalhadores rurais que produzem em regime de economia familiar, sem utilização de mão de obra assalariada. Também são considerados segurados especiais o pescador artesanal e o índio que exerce atividade rural, e os familiares que participam da produção (regime de economia familiar). Consultado a 13.10.2016, em http://socialprevidencia.net/segurado-especial-inss.html.
} 
além da perda do direito ao "Seguro Defeso", que é um benefício do governo brasileiro e que representa, durante o período de reprodução e recrutamento das espécies, a única fonte de renda de inúmeras famílias pescadoras. O pagamento do benefício, em valor de um salário mínimo, ${ }^{30}$ é alegado pelos participantes dos grupos focais como sendo insuficiente para o custeio de suas despesas normais, fazendo com que vários pescadores busquem outras atividades.

As discussões nos grupos focais ocorreram de maneira livre, apesar de os mediadores dos grupos conduzirem os debates com base em temas-chave, como já ressaltado. Repetidamente a "desunião" dos pescadores artesanais volta à pauta de discussão nos grupos. A falta de alternativas na venda do pescado, e a dependência da figura do atravessador, são tratadas como resultado desta desarticulação entre eles. A Tabela 4, também extraída do Censo PEA Pescarte, evidencia essa relação de dependência no que se refere à chamada "primeira venda" do pescado, que representa a principal fonte de renda destes trabalhadores. De acordo com os dados obtidos, quase $60 \%$ dos pescadores artesanais respondentes aos questionários se comprometem com acordos de venda feitos anteriormente com os atravessadores.

TABELA 4 - Com quem é feito o acordo da venda do pescado?

\begin{tabular}{llcccc}
\hline & Frequência & Porcentual & $\begin{array}{c}\text { Porcentagem } \\
\text { válida }\end{array}$ & $\begin{array}{c}\text { Porcentagem } \\
\text { acumulativa }\end{array}$ \\
\hline \multirow{2}{*}{$\begin{array}{l}\text { Com o } \\
\text { atravessador }\end{array}$} & 362 & 3,6 & 58,3 & 58,3 \\
\hline $\begin{array}{l}\text { Comerciantes } \\
\text { locais }\end{array}$ & 123 & 1,2 & 19,8 & 78,1 \\
\cline { 2 - 5 } & $\begin{array}{l}\text { Para terceiros } \\
\text { (desconhecidos) }\end{array}$ & 119 & 1,2 & 19,2 & 97,3 \\
\hline $\begin{array}{l}\text { Com donos de } \\
\text { outros barcos }\end{array}$ & 17 & 0,2 & 2,7 & 100,0 \\
\hline \begin{tabular}{l} 
Total \\
\hline
\end{tabular} & 621 & 6,2 & 100,0 & - \\
\hline
\end{tabular}

cont.

${ }^{30}$ O salário mínimo, em dezembro de 2015, era em moeda corrente de $\mathrm{R} \$ 788,00$. A cotação média entre as moedas Real $(\mathrm{R} \$)$ em relação ao Euro $(€)$, para o mês de dezembro de 2015, foi de $1,00 €$ para $4,24 \mathrm{R} \$$. 
cont.

\begin{tabular}{cccccc}
\hline & Frequência & Porcentual & $\begin{array}{c}\text { Porcentagem } \\
\text { válida }\end{array}$ & $\begin{array}{c}\text { Porcentagem } \\
\text { acumulativa }\end{array}$ \\
\hline \multirow{2}{*}{ Não se aplica } & 9376 & 93 & - & - \\
\cline { 2 - 6 } & Não respondeu & 81 & 0,8 & - & - \\
\cline { 2 - 6 } & Não sabe & 4 & 0,0 & - & - \\
\cline { 2 - 6 } & Total & 9461 & 93,8 & - & - \\
\hline Total & 10082 & 100,0 & - & - \\
\hline
\end{tabular}

Fonte: Questionário Censo PEA Pescarte, 2015.

O tema sobre a participação das mulheres na pesca foi também ponto de destaque nos grupos focais. Há uma dificuldade de as mulheres em se reconhecerem enquanto trabalhadoras da cadeia produtiva da pesca, bem como de os homens as reconhecerem como ocupantes deste papel na pesca. O "mar" é visto e analisado como território, por excelência, destinado ao homem e suas atividades produtivas, levando em conta o esforço físico e os níveis precários de trabalho a que esses pescadores estão expostos. Ficou visível que elas se configuram como o grupo mais vulnerável entre esses trabalhadores (Silva, 2013: 53). Há nos relatos das mulheres uma precarização do trabalho no que diz respeito aos salários, direitos e condições de trabalho. Quase sempre, são conduzidas a não reconhecerem a importância do seu trabalho e de sua incorporação à cadeia produtiva como pescadoras. Muitas foram as mulheres que descreveram sua rotina na cadeia produtiva da pesca, como um trabalho com níveis intensificados de exploração (Silva, 2013). Tais questões se evidenciam por exemplo, na comunidade do Terminal Pesqueiro, em Campos dos Goytacazes, em que as mulheres descreveram a atividade conhecida como "fundo de quintal", cuja dinâmica já traduz os níveis de precarização vivenciados cotidianamente por essas mulheres. O "fundo de quintal" consiste na reunião de mulheres para o descasque do camarão e filetagem do pescado - geralmente na casa da dona do "quintal" e que também é a responsável pelo recebimento do pescado vindo do atravessador. O preço pago pelos atravessadores a essas mulheres vai de $0,30 R \$$ a $2,50 R \$^{31}$ por quilo de pescado beneficiado. Um preço, segundo elas, bem abaixo do valor de mercado, visto que estes se destinam

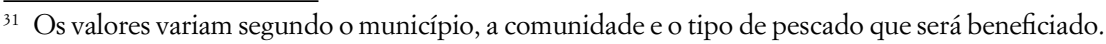


aos centros urbanos e que são vendidos a valores muito acima do que é pago na origem do produto. Autores como Charles Levkoe, Kristen Lowitt e Connie Nelson consideram tais discrepâncias, inclusive no pós-pesca, como um desafio que se coloca à pesca artesanal de pequena escala, em que pese os direitos das comunidades em ter um acesso justo ao fruto dessa produção. Trata-se, portanto, do direito dos pescadores em conduzirem e controlarem a sua produção, de forma autônoma e independente, a partir de iniciativas coletivas (Levkoe, Lowitt e Nelson, 2017).

O trabalho rotinizado, intensificado e precarizado se manifesta em todos os municípios cobertos pelo Projeto PEA Pescarte. O trabalho part-time, vinculado ao domicílio, é fortemente marcado pela informalidade, criando dificuldades para que estas mulheres tenham acesso a direitos constituídos e assegurados pela legislação trabalhista brasileira. Contudo, é fato que o trabalho feminino configura-se como uma fonte de renda importante para as famílias entrevistadas. Dados do Censo PEA Pescarte dão conta de que cerca de $20 \%$ das mulheres contribuem com $100 \%$ da renda do núcleo familiar e outras $42 \%$ contribuem com até $50 \%$.

Outra questão ressaltada pelos participantes dos grupos focais foi a relação com as colônias de pescadores. Há um descrédito sobre o papel destas, ao considerá-las ineficazes na resolução dos seus problemas. Foi apontado nos grupos focais que as mesmas, na maioria das vezes, não conseguem captar recursos para a pesca, sendo ainda comum a cooptação por relações clientelistas com o poder público municipal.

Deste modo, há uma clara apatia em relação às iniciativas de participação dos pescadores ouvidos nos grupos focais, no cotidiano das colônias das quais fazem parte. $^{32}$ Isso ocorre pela pouca capacidade que elas possuem de mobilização e aglutinação dos interesses dos pescadores. Alguns destes relataram que "não vale a pena participar das reuniões das colônias de pesca”, uma vez que não se sentem representados por suas lideranças, e tampouco têm suas demandas consideradas. A baixa participação nas reuniões, segundo foi ressaltado, ocorre porque em algumas situações, "a direção da colônia combina antes as decisões e resultados de votações". ${ }^{33}$ Este ponto é controverso, sobretudo quando se contrapõem tais posicionamentos com as falas dos integrantes destas colônias - aqueles que estavam presentes

\footnotetext{
${ }_{32}$ A atividade da pesca artesanal é regulada por legislação específica, podendo exercer a função legalmente aquele pescador que possuir uma carteira de identificação profissional, que concede o direito ao recebimento do benefício do Seguro Defeso. A emissão e controle dessa carteira é prerrogativa das colônias de pesca e das superintendências estaduais do Ministério.

${ }_{33}$ Reunião realizada com as lideranças da pesca em São Francisco do Itabapoana, em outubro de 2014 .
} 
nos grupos focais -, que afirmam que a não participação dos pescadores se deve ao fato de que não querem contribuir com as mensalidades da colônia. O que se percebe é que não há consenso entre os pescadores sobre o papel destas organizações junto às suas demandas.

A última seção deste artigo traz os achados e contribuições decorrentes do seminário sobre economia solidária, realizado na UENF, com a presença das lideranças e de pescadores. As análises são acrescidas também dos dados obtidos por meio do Censo PEA Pescarte.

\section{Perspectivas sobre economia solidária entre os pescadores artesanais: o relato de experiências e os dados do Censo do PEA Pescarte}

Num último esforço procura-se aqui realçar os desdobramentos do I Seminário de Economia Solidária do Projeto Pescarte: Práticas, Rumos e Possibilidades para a Emancipação Social, realizado na UENF, entre os dias 11 e 13 de novembro de 2015. A proposta de realizar este encontro partiu da coordenação e do grupo de pesquisa do Projeto PEA Pescarte. O encontro teve o intuito de trazer ao público, a maioria composto por pescadores, estudantes e pesquisadores, a discussão sobre os rumos para a construção de empreendimentos solidários e autogestionáveis, bem como alinhar o conceito de economia solidária a ser desenvolvido pelo Projeto. Foi possível ouvir teóricos sobre o tema e também participantes de experiências em economia solidária envolvendo a pesca artesanal, assim como difundir questões centrais com as quais os estudiosos da área assentam essa teoria:

No capitalismo, a riqueza é produzida coletivamente, mas é apropriada individualmente. Então, todos trabalham para que alguém acumule o excedente de produção. Já na economia solidária, se assumem os modelos cooperativos e a riqueza que é produzida socialmente, de forma coletiva, sendo também distribuída e apropriada coletivamente. $^{34}$

Destacou-se em todos os momentos do evento que "a força está no coletivo, embora esse coletivo também torne a gestão mais complexa, dada a exigência de um maior envolvimento nas decisões colegiadas", 35 em uma perspectiva de organização social. Caracterizar "os empreendimentos solidários como iniciativas que mexem com a economia, com a produção de bens, com a oferta de serviço, com geração de renda ou

\footnotetext{
${ }^{34}$ Fala de abertura proferida pelo coordenador do PEA Pescarte.

35 Fala de abertura proferida pelo professor Luiz Inácio Gaiger.
} 
com o cuidado dos bens" é dizer que esses empreendimentos precisam assumir compromissos com a sociedade local, com o município e com a região, e, para isso, é necessário que a gestão seja realmente democrática. ${ }^{36}$

No entanto, quando se conhece ou quando se ouve falar sobre as iniciativas e ações executadas pelos pescadores artesanais, pode-se dizer que há princípios claros de cooperação, apesar de um nível elevado de desconfiança, como se verificou por um lado. Por outro lado, as falas expressas nas reuniões e grupos focais, apontam que o trabalho coletivo é a saída mais plausível para uma condição de vida melhor e mais digna. E isso é o que se tem de mais importante, que está incutido nas opiniões de grande parte dos pescadores artesanais e permeia o cotidiano destes trabalhadores. Trata-se de um primeiro passo para que se possa dar vazão aos empreendimentos solidários, construídos coletivamente nos municípios cobertos pelo Projeto PEA Pescarte.

Como apontado anteriormente, embora se tenha a noção das melhorias que uma organização social de caráter produtivo poderia produzir, há uma descrença sobre estas iniciativas, o que requer um trabalho de mobilização e conquista da confiança dos pescadores. E isso não é nada simples. Em parte, porque as experiências de empreendimentos cooperativos em municípios da Bacia de Campos não foram frutíferas, como já foi abordado, mas também em decorrência dos resultados econômicos desses empreendimentos que não foram distribuídos de forma equitativa. Tais questões, paulatinamente, redundaram no afastamento da comunidade desses projetos. Os motivos são diversos, mas reforçam a questão da "desconfiança" e da falta de união entre os pescadores no que se refere a tais iniciativas, por vezes vistas como "sendo uma forma de tornar ricos a uns nas costas dos demais". 37

As Tabelas 5, 6 e 7 foram criadas a partir das respostas ao questionário do Censo PEA Pescarte, junto a todas as localidades com a presença de pescadores artesanais dos sete municípios pesquisados na Bacia de Campos. A partir da amplitude dos temas apresentados pelos questionários do Censo PEA Pescarte para os propósitos deste artigo, foram escolhidas (e apresentadas sequencialmente) as perguntas relacionadas ao trabalho coletivo. Afinal, é disso que parte o entendimento dos preceitos da economia solidária, baseados na ação conjunta, no trabalho coletivo e na organização social.

\footnotetext{
${ }^{36}$ Fala de abertura proferida pelo professor Luiz Inácio Gaiger.

${ }^{37}$ Fala proferida por um pescador marítimo em reunião realizada com as lideranças de Cabo Frio, em outubro de 2014.
} 
Cabe aqui um breve esclarecimento sobre algumas questões do questionário aplicado aos pescadores artesanais, e que reportam diretamente ao entendimento sobre os seus resultados. Por uma questão de método adotado na pesquisa, como se ressaltou anteriormente, esse primeiro ciclo tomou como base três elementos analíticos: as reuniões de apresentação e conhecimento do campo, os grupos focais aplicados junto às comunidades pesqueiras dos sete municípios, e o censo da pesca, respectivamente nessa ordem. As duas primeiras estratégias apontaram, de início e de forma contundente, a questão da desconfiança e o descrédito relacionado aos projetos ambientais. Não por uma questão de teimosia puramente, mas sim pelas experiências passadas com outros projetos coordenados pelas empresas de petróleo e gás que atuam no mesmo ambiente em que vivem e trabalham. $\mathrm{Na}$ maioria das vezes, essas ações foram interrompidas antes que alcançassem os seus objetivos. Ou seja, já havia uma pré-disposição negativa em relação a esses projetos de mitigação ambiental. Isso posto, com o PEA Pescarte, tem-se como novidade o fato de a universidade assumir o protagonismo de ser a instituição proponente e executora - não como um projeto top-down, cujas decisões partem de cima para baixo, mas sim a partir de uma construção coletiva e pactuada com as comunidades envolvidas.

Com efeito, as incursões iniciais no campo tiveram a prerrogativa de discutir o projeto e o seu desenho. Desse modo, a figura da universidade com os seus pesquisadores estabeleceu uma espécie de "contrato de confiança", avalizado por uma série de fatores, como a frequente permanência no campo, o recrutamento de jovens, filhos e filhas dos próprios pescadores no corpo técnico do projeto (alguns desses jovens, inclusive, já ingressaram em cursos oferecidos pela universidade). Assim, tais questões relacionadas ao ordenamento dos empreendimentos sociais foram elaboradas tendo a universidade como uma espécie de "instituição suporte". É sabido, porém, que esse procedimento pode condicionar as respostas. No entanto, foi um risco assumido pela pesquisa.

Os dados apontam um contraste entre resultados encontrados a partir das respostas dos questionários, com a propalada descrença e desconfiança ilustradas nas primeiras abordagens de campo evidenciadas aqui, pelas reuniões ampliadas e grupos focais. Assim, como já foi ressaltado e, dadas as evidências quanto à desconfiança dos pescadores em relação às empresas petrolíferas que atuam na região, optou-se por dar um destaque maior à universidade enquanto parceira na construção de um projeto com esse caráter solidário e participativo, inclusive em algumas perguntas do próprio questionário. Como se pode verificar na Tabela 5 , o equivalente a $93 \%$ dos entrevistados disse que participaria de uma cooperativa, ou associação, 
ou pequena empresa, ou uma unidade produtiva. Esse dado demonstra a intenção que é refletida nas respostas.

TABELA 5 - Se houvesse uma cooperativa/associação/pequena empresa/unidade produtiva na sua comunidade administrada pelos pescadores locais e pela universidade, daria preferência na venda de seu pescado para ela?

\begin{tabular}{llcccc}
\hline & & Frequência & Porcentual & $\begin{array}{c}\text { Porcentagem } \\
\text { válida }\end{array}$ & $\begin{array}{c}\text { Porcentagem } \\
\text { acumulativa }\end{array}$ \\
\hline \multirow{4}{*}{ Válido } & \multicolumn{1}{c}{ Sim } & 2981 & 29,6 & 93,0 & 93,0 \\
\cline { 2 - 6 } & Não & 226 & 2,2 & 7,0 & 100,0 \\
\cline { 2 - 6 } & Total & 3207 & 31,8 & 100,0 & - \\
\hline \multirow{2}{*}{ Ausente } & Não se aplica & 6684 & 66,3 & - & - \\
\cline { 2 - 6 } & Não sabe & 100 & 1,0 & - & - \\
\cline { 2 - 6 } & Não respondeu & 91 & 0,9 & - & - \\
\cline { 2 - 6 } & Total & 6875 & 68,2 & - & - \\
\hline \multirow{2}{*}{ Total } & \multirow{2}{*}{60082} & 100,0 & - & - \\
\hline
\end{tabular}

Fonte: Questionário Censo PEA Pescarte, 2015.

As razões que os respondentes alegam para participar são dadas na Tabela 6 , sendo que a principal, com $51,5 \%$, é a garantia de aumento da renda, seguida por $23,6 \%$ que afirmam que possibilitaria uma organização maior dos trabalhadores, enquanto outros $12,4 \%$ afirmam que participariam para evitar a compra do pescado pelos atravessadores.

Os dados da Tabela 7, apontam uma inversão nas expectativas de participação dos filhos na atividade pesqueira. Quando questionados se querem que seus filhos participem da pesca, cerca de $89 \%$ dos pescadores responderam que não querem que seus filhos trabalhem na pesca, e dentre os motivos apontados prevalece a instabilidade da renda da pesca. Contudo, quando perguntados se gostariam que eles participassem de uma cooperativa, associação, pequena empresa ou unidade produtiva, tem-se que $67,7 \%$ gostariam que seus filhos participassem desse empreendimento. Esse dado revela uma postura contrária àquela assumida anteriormente pelos pescadores nas reuniões e grupos focais, onde foram categóricos 
quanto à descrença no futuro dos seus filhos na pesca. Agora, com a figura da universidade, tais questões passam a ser reconsideradas pelas famílias dos pescadores - elevando o custo dessa responsabilidade -, o que acrescenta uma possibilidade de que a pesca possa se renovar por meio dos descendentes. Além disto, há uma aposta de que, na possibilidade de ser executada uma associação ou cooperativa produtiva, seus filhos possam participar e sejam atraídos pela atividade da pesca, uma vez que tenham condições mais rentáveis de viver desta atividade.

TABELA 6 - Por que aceitaria fazer parte desta cooperativa/associação/pequena empresa/unidade produtiva?

\begin{tabular}{|c|c|c|c|c|c|}
\hline & & Frequência & Porcentual & $\begin{array}{l}\text { Porcentagem } \\
\text { válida }\end{array}$ & $\begin{array}{l}\text { Porcentagem } \\
\text { acumulativa }\end{array}$ \\
\hline \multirow{9}{*}{ Válido } & Garante o aumento da renda & 1449 & 14,4 & 51,5 & 51,5 \\
\hline & $\begin{array}{l}\text { Permite a organização dos } \\
\text { trabalhadores }\end{array}$ & 663 & 6,6 & 23,6 & 75,1 \\
\hline & $\begin{array}{l}\text { Evitaria a venda para o(a) } \\
\text { atravessador(a) }\end{array}$ & 348 & 3,5 & 12,4 & 87,5 \\
\hline & Facilita o acesso ao mercado & 143 & 1,4 & 5,1 & 92,6 \\
\hline & $\begin{array}{l}\text { Garante a competitividade no } \\
\text { mercado }\end{array}$ & 105 & 1,0 & 3,7 & 96,3 \\
\hline & Barateia os custos da produção & 63 & 0,6 & 2,2 & 98,5 \\
\hline & Facilita o acesso a linhas de créditos & 33 & 0,3 & 1,2 & 99,7 \\
\hline & Todas as opções listadas & 8 & 0,1 & 0,3 & 100,0 \\
\hline & Total & 2812 & 27,9 & 100,0 & - \\
\hline \multirow{4}{*}{ Ausente } & Não se aplica & 7221 & 71,6 & - & - \\
\hline & Não sabe & 34 & 0,3 & - & - \\
\hline & Não respondeu & 15 & 0,1 & - & - \\
\hline & Total & 7270 & 72,1 & - & - \\
\hline Total & & 10082 & 100,0 & - & - \\
\hline
\end{tabular}

Fonte: Questionário Censo PEA Pescarte, 2015. 
TABELA 7 - Gostaria que seu filho ou sua filha participasse desta cooperativa/associação/pequena empresa/unidade produtiva?

\begin{tabular}{llcccc}
\hline & & Frequência & Porcentual & $\begin{array}{c}\text { Porcentagem } \\
\text { válida }\end{array}$ & $\begin{array}{c}\text { Porcentagem } \\
\text { acumulativa }\end{array}$ \\
\hline \multirow{4}{*}{ Válido } & Sim & 2012 & 20,0 & 67,7 & 67,7 \\
\cline { 2 - 6 } & Não & 959 & 9,5 & 32,3 & 100,0 \\
\cline { 2 - 6 } & Total & 2971 & 29,5 & 100,0 & - \\
\hline \multirow{3}{*}{ Ausente } & Não sabe & 6783 & 67,3 & - & - \\
\cline { 2 - 6 } & Não sabe & 214 & 2,1 & - & - \\
\cline { 2 - 6 } & Não respondeu & 114 & 1,1 & - & - \\
\cline { 2 - 6 } & Total & 7111 & 70,5 & - & - \\
\hline \multirow{2}{*}{ Total } & 10082 & 100,0 & - & - \\
\hline
\end{tabular}

Fonte: Questionário Censo PEA Pescarte, 2015.

Os dados foram apresentados sequencialmente nesta seção por uma questão simples: a falta de confiança relatada em boa parte dos levantamentos de campo compõe um extremo analítico; na outra ponta, evidencia-se, claramente, a questão da solidariedade entre os pescadores, além do interesse em ações cooperativas, como se observou nas respostas ao Censo PEA Pescarte. Os questionários mostraram que em mais de $87 \%$ das respostas em todos os sete municípios, os entrevistados aceitariam participar de uma cooperativa na qual tivessem capacidade de gestão, porém, em parceria com a universidade. E mais de $90 \%$ afirmaram que destinariam o seu pescado para esta cooperativa. Mais uma vez, a confiança que a universidade transmite representou um papel preponderante nas respostas dos entrevistados, como foi dito anteriormente.

E, nesse contexto, estimulariam ainda os seus filhos a participarem deste empreendimento solidário - esta resposta apareceu em quase $68 \%$ dos entrevistados. Em outras palavras, se por um lado impera a desconfiança, por outro há um cenário de potencial cooperação entre os pescadores. Portanto, trata-se de um terreno fértil para que se possam implementar empreendimentos solidários, com o apoio da universidade, que é um 
grande ponto de apoio dessas iniciativas. Inclusive no sentido de fomentar a cooperação e a ajuda mútua entre os pescadores.

As experiências de pescadores artesanais relatadas no seminário puxaram esse debate dizendo que, "[...] para a economia solidária o ponto de partida é a organização coletiva, podendo ser uma associação, uma cooperativa, ou um grupo formal, mas sempre o princípio é o da autogestão" ${ }^{38} \mathrm{E}$ isso não é simples. Tem um problema crucial que é "a organização social que vai estar por detrás deste empreendimento".

Acontece que um empreendimento com esta característica esbarra na confiança mútua. E o único jeito de se conquistar a confiança é "fazendo juntos, com a clareza do que está sendo feito". ${ }^{39}$ Afinal, "é muito difícil criar um empreendimento onde toda comunidade adere no primeiro momento", ${ }^{40}$ mesmo que o trabalho em grupo possa beneficiar toda a comunidade. E o difícil está exatamente em começar. Mesmo porque a construção deste modelo solidário implica um resgate cultural, em que pese a "importância da tradição dentro de um negócio, dentro de um cooperativismo, que você está resgatando a cultura, o estilo daquele povo que vai fazer o empreendimento". ${ }^{41}$

Por fim, vale ressaltar um aspecto importante que aguçou a atenção dos pescadores presentes no seminário, que foi a fala do professor Luiz Inácio Gaiger, ao afirmar que "muitas vezes, os pescadores praticam a economia solidária e não sabem". Atuam por meio de procedimentos "informais, tradicionais; onde as pessoas nem dão muito nome pra isso. Faz parte da vida cotidiana. Já é uma rotina. É solidariedade de quem tem isso quase no seu DNA" ${ }^{42} \mathrm{E}$ a economia solidária é uma resposta econômica que permite as pessoas adquirirem qualidade de vida, com preservação ambiental, desenvolvimento social e sustentabilidade.

\section{Considerações finais}

O fortalecimento das relações políticas e sociais entre os pescadores artesanais tornou-se essencial nos primeiros anos do Projeto PEA Pescarte. É resultado da ação do projeto ao produzir um intercâmbio de informações e de negociações entre os atores envolvidos. Neste sentido, pode-se perceber a quebra de padrões usuais em que se destacavam posições menos participativas por parte de algumas lideranças, cujas decisões nem sempre ocorriam de maneira

\footnotetext{
${ }^{38}$ Fala de abertura proferida pelo coordenador do PEA Pescarte.

${ }^{39}$ Fala proferida pelo pescador Nêgo da Pesca, da Associação de Pescadores de Jacareípe, Espírito Santo.

${ }^{40}$ Ver nota de rodapé n. ${ }^{\circ} 39$.

${ }^{41}$ Ver nota de rodapé n. ${ }^{\circ} 39$.

${ }^{42}$ Fala de abertura proferida pelo professor Luiz Inácio Gaiger.
} 
consensual. No seu lugar, começa a aparecer uma "maior autonomia", cujos efeitos são percebidos nas próprias falas dos pescadores.

Ao longo do primeiro ciclo, os dois primeiros anos da pesquisa, pode-se dizer que uma das principais contribuições do PEA Pescarte, segundo os próprios pescadores e familiares, foi a capacidade de escutar e dar voz a este grupo, historicamente silenciado em suas necessidades econômicas, sociais e políticas. Tais "mudanças" ganharam mais evidência a partir de intermediações que, por meio do confronto e da mediação de propostas e interesses, vem sendo capaz de produzir decisões mais democráticas e baseadas em cooperação.

Ao se olhar o caminho percorrido pelo PEA Pescarte nesse período, com seus mais de 80 técnicos sociais e pesquisadores, foi possível identificar ações e empreendimentos com tais características. O entrave do resgate da confiança comunitária e nas instituições se revelou um enorme desafio. Mas também, as certezas de que uma solução possível passa pela cooperação entre eles. São, portanto, sentimentos extremados, mas que, uma vez conduzidos adequadamente, podem transformar a "desconfiança em vigília". E isso é essencial para o funcionamento de qualquer empreendimento social, uma vez que reflete na maior transparência das ações.

Este cenário aponta para uma amplificação das possibilidades da configuração de empreendimentos solidários entre os pescadores artesanais na Bacia de Campos, o que pode alterar significativamente a realidade socioeconômica destes sujeitos.

Enfim, de todo esse esforço empreendido ao longo desse período da pesquisa, pode-se dizer que, a partir de uma postura mais intervencionista por parte da universidade - assumindo o papel e a responsabilidade de conduzir um projeto de geração de trabalho e renda, embasado nos princípios da economia solidária -, foi possível identificar (e despertar) entre os pescadores da Bacia de Campos um potencial de organização social ainda pouco explorado. Trata-se, portanto, de uma confiança avalizada pela universidade e que se reflete na figura do projeto, como uma possibilidade de equacionar problemas do cotidiano dos pescadores artesanais, como a escassez do pescado e a exploração praticada pelos atravessadores questões que eles não conseguem enfrentar sozinhos. Em outras palavras, a universidade pode (e deve) ser um aliado destas populações tradicionais, mas consciente da responsabilidade que tem pelas expectativas que cria através destas iniciativas.

Revisto por Sofia Silva 


\section{Referências bibliográficas}

Alves, Francisco; Salomão, Silvana (2012), "Economia solidária e empreendedorismo: vertentes antagônicas ou parceiras na geração de trabalho e renda?”, in Isabel Georges; Márcia de Paula Leite (orgs.), Novas configurações do trabalho e economia solidária. São Paulo: Annablume, 351-376.

Caccia Bava, Silvio (2004), "Tecnologia social e desenvolvimento local", in VV. AA., Tecnologia social: uma estratégia para o desenvolvimento. Rio de Janeiro: Fundação Banco do Brasil, 103-116.

Campos, Mauro Macedo; Timóteo, Geraldo Márcio; Silva, Teófilo Augusto da (2015), "Responsabilidade social offshore: ausência do Estado, incentivos privados e ressonância da fala dos pescadores artesanais", WATERLAT-GOBACIT Network Working Papers - Inequality, injustice, and social change: the fate of artisanal fishing communities in Latin America, 2(4), 154-172.

Capellesso, Adinor José; Cazella, Ademir Antonio (2011), "Pesca artesanal entre crise econômica e problemas socioambientais: estudo de caso nos municípios de Garopaba e Imbituba (SC)", Revista Ambiente \& Sociedade, XIV(2), 15-33.

Censo PEA Pescarte (2015), Projeto de mitigação ambiental PETROBRAS/IBAMA/ /UENF. Campos dos Goytacazes.

Coraggio, José Luis (2016), "Movimientos sociales y economía”, in José Luis Coraggio (org.), Economía social y solidaria en movimiento. Los Polvorines, Argentina: Ediciones UNGS - Universidad Nacional de General Sarmiento, 15-39 [1. ${ }^{\text {e ed.]. }}$

Cunha, Altivo Roberto Andrade de Almeida (2015), “Abastecimento alimentar: a superação do padrão velho-obsoleto para o novo-ancestral”, in Sergio Schneider; Fabiana Thomé da Cruz; Alessandra Matte (orgs.), Alimentos para produtores e consumidores: conectando novas estratégias de abastecimento de alimentos. Porto Alegre: Editora da UFRGS - Universidade Federal do Rio Grande do Sul, 54-70.

FAO - Food and Agriculture Organization of the United Nations (2015), Voluntary Guidelines for Securing Sustainable Small-Scale Fisheries: In the Context of Food Security and Poverty Eradication. Roma: FAO.

Gaiger, Luiz Inácio (2007), “A outra racionalidade da economia solidária. Conclusões do primeiro Mapeamento Nacional no Brasil”, Revista Crítica de Ciências Sociais, 79, 57-77.

Gaiger, Luiz Inácio (2008), “A dimensão empreendedora da economia solidária: notas para um debate necessário”, Otra Economia: Revista Latinoamericana de Economía Social y Solidaria, II(3), 58-72.

Gaiger, Luiz Inácio (2013), “A economia solidária e a revitalização do paradigma cooperativo”, Revista Brasileira de Ciências Sociais, 28(82), 211-228.

Garcez, Danielle Sequeira; Sánches-Botero, Jorge Iván (2005), “Comunidades de pescadores artesanais no estado do Rio Grande do Sul, Brasil”, Atlântica, Rio Grande, 27(1), 17-29. 
Lassance Júnior, Antonio Ernesto Albuquerque; Pedreira, Juçara Santiago (2004), "Tecnologias sociais e políticas públicas", in VV. AA., Tecnologia social: uma estratégia para o desenvolvimento. Rio de Janeiro: Fundação Banco do Brasil, 65-82.

Laville, Jean-Louis (2009), “A economia solidária: um movimento internacional”, Revista Crítica de Ciências Sociais, 84, 7-47.

Laville, Jean-Louis; Gaiger, Luiz Inácio (2009), “Economia solidária”, in Antonio David Cattani; Jean-Louis Laville; Luiz Inácio Gaiger; Pedro Hespanha (coords.), Dicionário internacional da outra economia. Coimbra: CES/Almedina.

Levkoe, Charles Z.; Lowitt, Kristen; Nelson, Connie (2017), “'Fish as Food': Exploring a Food Sovereignty Approach to Small-Scale Fisheries”, Marine Policy, 85, 65-70.

Maldonado, Fabiana; Santos, Antônio Carlos dos (2006), "Cooperativas de pescadores artesanais: uma análise sob a perspectiva teórica”, Organizações Rurais \& Agroindustriais, 8(3), 323-333.

Ramires, Milena; Molina, Silvia Maria Guerra; Hanazaki, Natalia (2007), "Etnoecologia caiçara: o conhecimento dos pescadores artesanais sobre aspectos ecológicos da pesca", Biotemas, 20(1), 101-113.

Santos, Boaventura de Sousa (2002), "Para uma sociologia das ausências e uma sociologia das emergências”, Revista Crítica de Ciências Sociais, 63, 237-280.

Santos, Boaventura de Sousa (2003), "Um mapa de alternativas de produção", in Boaventura de Sousa Santos (org.), Produzir para viver: os caminhos da produção não capitalista. Porto: Afrontamento, 28-49.

Silva, Patrícia Araújo (2013), O mar é masculino? O trabalho das mulheres na maricultura, ponta da Ilha/Jurujuba, Niterói/RJ. Dissertação de Mestrado apresentada ao Centro de Pesquisa em Desenvolvimento, Sociedade e Agricultura (CPDA), Universidade Federal Rural do Rio de Janeiro (UFRRJ), Seropédica, Brasil.

Singer, Paul (2002), Introdução à economia solidária. São Paulo: Editora Fundação Perseu Abramo [1 $1^{\mathrm{a}}$ ed.].

Artigo recebido a 08.11.2016

Aprovado para publicação a 12.03.2018

\section{Mauro Macedo Campos}

Universidade Estadual do Norte Fluminense Darcy Ribeiro

Av. Alberto Lamego, 2000, Parque Califórnia, CEP 28035-200, Campos dos Goytacazes (RJ), Brasil Contacto: mauromcampos@yahoo.com.br 


\title{
Geraldo Márcio Timóteo
}

Universidade Estadual do Norte Fluminense Darcy Ribeiro

Av. Alberto Lamego, 2000, Parque Califórnia, CEP 28035-200, Campos dos Goytacazes (RJ), Brasil

Contacto: geraldotimoteo@gmail.com

\author{
Ana Paula Serpa Nogueira de Arruda \\ Universidade Candido Mendes \\ Unidade Campos - Rua Anita Peçanha, 100, Parque São Caetano, CEP 28030-335, Campos dos \\ Goytacazes (RJ), Brasil \\ Contacto: serpanogueira@gmail.com
}

\section{The Dynamics of Artisanal Fisheries in the Bacia de Campos: Social Organization and Practices in Solidarity Economy among Artisanal Fishermen}

This article presents the challenges to the implementation of a solidarity economy project with artisanal fishermen in the Bacia de Campos, Brazil. The study is the result of research conducted by PEA Pescarte Project, a partnership between UENF/Petrobras/IBAMA. The information in this study was collected in meetings in fishing communities, focus groups and from questionnaires made for census purposes. The findings highlight the artisanal fishermen's lack of confidence in state and representative institutions. On the other hand, they point to the solidarity and the view that the work carried out with cooperation and social organization are essential for changing the socio-economic reality of these individuals.

Keywords: artisanal fishing; environmental education; social organization; solidarity economy.

\section{La dynamique de la pêche artisanale à Bacia de Campos: organisation sociale et pratiques de l'économie solidaire entre pêcheurs}

Cet article présente les défis que représente la mise en œuvre d'un projet d'économie solidaire avec les pêcheurs dans le Bacia de Campos, au Brésil. La recherche est le résultat de différentes études menées par le Projet PEA Pescarte, en partenariat avec UENF/Petrobras/IBAMA. Les informations contenues dans cette recherche ont été recueillies par le biais de différentes méthodes: entretiens de groupe (focus group) réunions dans les communautés de pêcheurs, groupes de discussion et enquête par questionnaires appliqués à la population de pêcheurs (recensement). Les résultats mettent en évidence le manque de confiance des pêcheurs artisanaux dans les institutions étatiques et représentatives. D'autre part, ils soulignent l'importance d'un travail coopératif dans la perspective de l'économie solidaire pour changer la réalité socio-économique de la population des pêcheurs.

Mots-clés: économie solidaire; éducation environnementale; organisation sociale; pêche artisanale. 